\title{
SISTEM INFORMASI GEOGRAFIS PENGELOMPOKAN TINGKAT KRIMINALITAS KOTA MALANG MENGGUNAKAN METODE K-MEANS
}

\author{
Danang Sutejo, Yosep Agus Pranoto, Hani Zulfia Zahro \\ Program Studi Teknik Informatika S1, Fakultas Teknologi Industri \\ Institut Teknologi Nasional Malang, Jalan Raya Karanglo km 2 Malang, Indonesia \\ danangsutejo78@gmail.com
}

\begin{abstract}
ABSTRAK
Kota malang menjadi salah satu kota pendidikan dengan jumlah perguruan tinggi lebih dari 80 lokasi, hal ini membuat padatnya tingkat penduduk dan membuka peluang tinggi terjadinya kriminalitas terutama bagi masyarakat umum dan khususnya para mahasiswa baru yang belum banyak mengetahui mengenai daerah rawan kriminal di Kota Malang. Sebagai solusi masalah ini diperlukan sistem informasi geografis yang secara khusus menampilkan informasi mengenai daerah persebaran lokasi yang mempunyai kerawanan kriminal.

Sistem yang akan dibangun yaitu sebuah sistem informasi geografis Pengelompokan tingkat kriminalitas Kota Malang ini dibuat menggunakan QGIS 2.18 dengan mengkombinasikan metode clustering. Salah satu metode Clustering adalah dengan menggunakan metode K-Means dengan menggunakan pengujian keakuratan menggunakan Davies-Bloudin Index.

Penerapan dari hasil clustering yang dilakukan menunjukan bahwa hasil clustering menggunakan $K$ Means menghasilkan percobaan 3 cluster yang memiliki hasil analisis keakuratan terkecil menggunakan Davies Bouldin Index yaitu sebesar 2,401 dengan pembagian daerah intensitas aman(C1) yaitu Kecamatan Kedungkandang, dalam cluster (C2) cukup rawan yaitu Kecamatan Blimbing, dalam cluster (C3) rawan yaitu kecamatan Klojen, Sukun dan dalam cluster sangat rawan (C4) yaitu kecamatan Lowokwaru. Pada pengujian user yang telah dilakukan, user memilih sangat baik adalah 32\%, memilih baik 55\%, memilih cukup baik $13 \%$ dan memilih kurang baik 0\% kemudian hasil pengujian fungsionalitas aplikasi pada browser yang berbeda, sudah berjalan dengan baik.
\end{abstract}

Kata Kunci : Sistem Informasi Geografis, Kriminalitas, K-Means, Kota Malang.

\section{PENDAHULUAN}

\subsection{Latar Belakang}

Kota Malang merupakan salah satu Kota dengan julukan Kota Pendidikan di Jawa Timur, Julukan ini muncul lantaran banyaknya jumlah kampus dan sekolah yang ada di Kota Malang. Terdapat setidaknya lebih dari 80 Perguruan Tinggi yang tersebar di wilayah Kota Malang.

Dengan padatnya tingkat kependudukan ini, membuka peluang tinggi terjadinya kriminalitas trutama bagi masyarakat umum dan khususnya para mahasiswa baru yang belum banyak mengetahui mengenai daerah rawan kriminal di Kota Malang. Data kepolisian mencatat sepanjang tahun 2017 kasus kriminalitas di Kota Malang mencapai 1.535 [1]. Diantaranya adalah kasus curanmor (Pencurian kendaraan bermotor) sebanyak 943 kasus, curas (pencurian dengan kekerasan) sebanyak 33 kasus, Senjata Tajam (sajam) 5 kasus, curat (pencurian dengan pemberatan) sebanyak 238 kasus, Curi biasa (Ordinary Stealing) 316 kasus.

Sementara ini belum terdapat suatu sistem informasi geografis di Kota Malang mengenai tingkat kriminalitas yang dapat dijadikan acuan sebagai tindakan preventif terhadap kejahatan, sedangkan saat ini informasi mengenai kriminalitas masih berupa data angka yang setiap tahunnya dikeluarkan oleh Badan Pusat Statistik (BPS) Kota Malang, kekurangan dari data yang di keluarkan BPS tersebut adalah datanya masih bersifat akumulatif dari beberapa kecamatan di Kota Malang, sehingga detail dari data mengenai lokasi, waktu dan tanggal kejadian belum ada.

Oleh karena itu penulis bermaksud membuat sistem informasi geografis tingkat kriminalitas Kota Malang yang memberikan informasi secara detail lokasi daerah rawan kriminal berdasarkan kecamatan dan informasi mengenai pengelompokan tingkat kerawanan tiap daerah kecamatan di Kota Malang, sehingga bagi mahasiswa dan masyarakat umum dapat membantu dalam mengambil keputusan pencegahan terhadap kasus kriminalitas.

\subsection{Rumusan Masalah}

Berdasarkan permasalahan yang terindetifikasi diatas, maka dapat dirumuskan beberapa rumusan masalah sebagai berikut:

1. Bagaimana merancang dan membangun sistem informasi geografis pengelompokan tingkat kriminalitas Kota Malang menggunakan metode K-means?

2. Bagaimana Menginformasikan peta persebaran Kriminalitas Kota Malang dalam sebuah website? 


\subsection{Batasan Masalah}

Berdasarkan pembuatan aplikasi ini terdapat beberapa batasan dalam pembuatan yaitu sebagai berikut:

1. Aplikasi ini berbasis Web.

2. Aplikasi ini dibuat dengan software Qgis version 2.18 dan database PhpMyAdmin.

3. Pemetaan menampilkan data kriminalitas pada tingkat kecamatan di Kota Malang (Lowokwaru, Sukun, Kedungkandang, Blimbing dan Klojen)

4. Objek penelitian adalah data kasus kriminal dari Polres Kota Malang Tahun 2019 (Januari-September).

5. Parameter yang digunakan adalah jumlah kejadian kriminalitas untuk 5 kategori, yaitu : Pencurian dengan kekerasan (curas), Pencurian dengan pemberatan (curat), Curanmor, Penadahan, Penganiayaan.

6. Perancangan aplikasi sistem informasi geografis dalam menyajikan informasi tindak kriminal di Kota Malang dengan metode clustering K-Means.

7. Target pengguna yaitu mahasiswa dan masyarakat umum.

\subsection{Tujuan}

Adapun tujuan yang akan dicapai pada penelitian ini:

1. Mengembangkan sebuah aplikasi berbasis Web yang dapat memberikan informasi mengenai persebaran kriminalitas di Kota Malang.

2. Mengetahui daerah tingkat kerawanan kriminalitas Kota Malang.

\subsection{Manfaat}

Adapun manfaat dalam penelitian ini adalah sebagai berikut :

1. Memberikan masukan informasi kepada Polres Kota Malang terkait dengan pantauan daerah yang berpotensi terjadi tindak kejahatan, sehingga dapat menjadi masukan tentang perkiraan lokasi yang aman dan rawan akibat tindak kejahatan yang terjadi.

2. Memberikan sumbangan penelitian untuk pengembangan ilmu yang berkaitan dengan tingkat kerawanan kriminalitas.

\section{Tinjaun Pustaka}

\subsection{Penelitian Terkait}

Perkembangan Beberapa keterkaitan dari penelitian yang di lakukan sebelumnya merupakan penelitian mengenai lembaga Polres Solok Kota yang masih melakukan pencatatan di papan tulis mengenai informasi kasus kriminalitas di Kota Solok yang terjadi setiap bulannya, sehingga informasi tersebut tidak sampai kepada masyarakat. Dengan adanya Sistem Informasi Geografis Titik Lokasi Daerah Rawan Kriminalitas di Kota Solok, masyarakat dapat memantau perkembangan dari masing-masing daerah melalui tingkat kerawanan kriminalitas dan analisis yang terdapat pada sistem[2].

Penelitian Selanjutnya mengangkat masalah mengenai Kasus tindakan kriminal di wilayah hukum Pengadilan Negeri Tasikmalaya hanya berupa jumlah kejadian kriminal perbulan tidak menunjukan alamat lengkap tempat terjadinya kriminal. Hasil dari penelitian tersebut yaitu Agar Proses pengolahan data yang berjalan saat ini digantikan dengan menggunakan komputerisasi yaitu Sistem Informasi Geografis untuk memfasilitasi pengolahan data kriminal tersebut[3].

Kemudian Penelitian membahas mengenai pencatatan kejadian kriminalitas yang saat ini masih dicatat dalam bentuk manual statistik tabel. Dengan cara tersebut kurang dapat diwakili secara spasial, sehingga pengambilan keputusan untuk penanganan kasus untuk semua kantor kepolisian Kota Yogyakarta menjadi sulit dan membutuhkan waktu yang lama[4].

Selanjutnya penelitian yang mengangkat masalah mengenai aplikasi pelaporan khususnya berbasis android mulai banyak dikembangkan tetapi masih menggunakan metode yang sama dengan aplikasi pelaporan lainnya yaitu mengirim foto atau video kejadian, lokasi kejadian (latitude dan longitude) pelapor, dan data pendukung lainnya. Akan tetapi masih bersifat pada daerahdaerah tertentu saja. Hasil Dengan diterapkannya aplikasi lapor Polri ini kepada masyarakat memungkinkan terjadinya kesinambungan dan peran aktif masyarakat dalam mengatasi tindak kejahatan di lingkungan sekitar[5].

Berikutnya penelitian mengenai banyaknya kejadian kriminal di berbagai tempat dengan waktu yang berbeda, menjadi kendala bagi pihak terkait untuk menentukan daerah yang memiliki tingkat kerawanan kriminalitas tinggi, Hasil yang di peroleh dari penelitian ini adalah berupa jumlah kriminalitas yang terjadi dan kategori wilayah tersebut, yaitu tingkat kriminalitas rendah, sedang, atau tinggi. Sistem ini dibantu juga oleh Metode Single Exponential Smoothing untuk meramalkan kejahatan yang terjadi pada bulan berikutnya[6].

\subsection{Dasar Teori}

\subsubsection{Sistem Informasi Geografis}

Sistem informasi geografis merupakan teknologi untuk mengelola, menganalisis dan menyebarkan informasi geografis yang berkaitan dengan tata letak keruangan dan informasiinformasi yang terkait. Berkaitan dengan sumber daya alam, maka informasi geografis akan berisi mengenai lokasi suatu daerah dan informasi mengenai sumber daya alam yang terkandung pada daerah tersebut. Perubahan-perubahan yang terjadi kapan saja pada alam berkaitan dengan penambahan atau pengurangan data akan dapat 
dilakukan secara uptodate tanpa harus membuat baru[7].

\subsubsection{Polres Malang}

Kepolisian Resort Malang atau Polres Malang adalah pelaksana tugas Kepolisian Negara Republik Indonesia di wilayah Kota Malang. Polres Malang merupakan Polres dengan klasifikasi (tingkat) B, sehingga kepala kepolisian resort yang menjabat seorang perwira menengah berpangkat Ajun Komisaris Besar Polisi (AKBP). Markas Kepolisian Resort Malang (Mapolres Malang) beralamat di Jalan. Jaksa agung suprapto 19 Samaan Kec.Klojen Malang, Jawa Timur. Polres Malang saat ini dipimpin oleh AKBP Dony Alexander,S.I.K.,M.H. Jajaran Polres Malang yaitu Polsek Ampel gading, Polsek Bantur, Polsek Bululawang, Polsek Dampit, Polsek Dau, Polsek Donomulyo, Polsek Gedangan, Polsek Gondanglegi, Polsek Jabung, Polsek Kalipare, Polsek Karangploso, Polsek Kepanjen, Polsek Kromengan, Polsek Lawang, Polsek Nganjum, Polsek Pagak, Polsek Pagelaran, Polsek Pakis, Polsek Pakisaji, Polsek Poncokusumo, Polsek Singosari, Polsek Sumbermanjing Wetan, Polsek Sumberpucung, Polsek Tajinan, Polsek Tirtoyudo, Polsek Tumpang, Polsek Turen, Polsek Wagir, Polsek Wajak dan Polsek Wonosari.

\subsubsection{Konsep Model Data Spasial pada SIG}

Data spasial merupakan data yang paling penting dalam SIG. Data spasial ada 2 macam yaitu data raster dan data vector.

\subsubsection{Data Raster}

Model data raster menampilkan, menempatkan dan menyimpan spasial dengan menggunakan struktur matriks atau pixel-pixel yang membentuk grid. Akurasi model data ini sangat bergantung pada resolusi atau ukuran pixelnya (sel grid) di permukaan bumi. Contoh data raster adalah citra satelit misalnya Spot, Landsat, dll. Konsep model data ini adalah dengan memberikan nilai yang berbeda untuk tiap-tiap pixel atau grid dari kondisi yang berbeda, Seperti Gambar 2.1

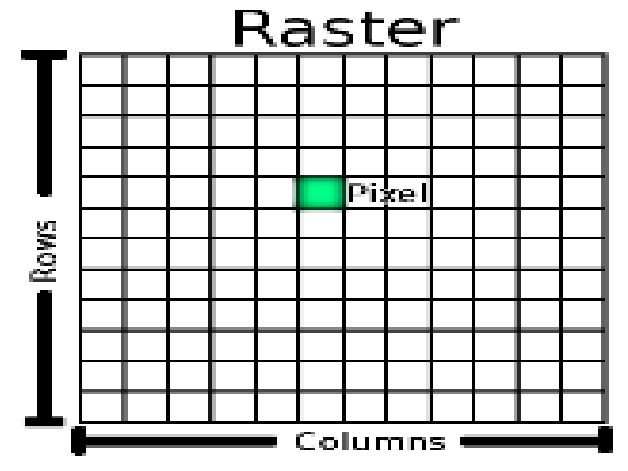

Gambar 2.1. Data vektor

\subsubsection{Data Vektor}

Model data vektor yang menampilkan, menempatkan dan menyimpan data spasial dengan menggunakan titik-titik, garis-garis, atau kurva atau poligon beserta atribut atributnya. Bentuk dasar representasi data spasial didalam sistem model data vektor, didefinisikan oleh sistem koordinat kartesian dua dimensi $(\mathrm{x}, \mathrm{y})$

\subsubsection{QGIS}

QGIS menjadi salah satu studi area pada penelitian ini dan merupakan perangkat lunak pengolah SIG yang bersifat Open Source yang user friendly. QGIS dapat dijalankan diberbagai macam system operasi, contohnya pada Linux, Unix, Mac, OSX, Windows dan Android. QGIS memiliki banyak format dan fungsionalitas pada vektor, raster dan basisdata[9].

\subsubsection{Clustering}

Clustering atau analisis pengelompokkan merupakan suatu proses membagi data dari suatu himpunan tertentu kedalam beberapa kelompok yang mempunyai kesamaan karakteristik data dengan karakteristik data dalam kelompok lain[10].

\subsubsection{K-Means}

K-Means adalah salah satu metode clustering berjenis non hirarki yang mempartisi data penelitian ke dalam bentuk beberapa cluster atau kelompok sehingga data yang mempunyai karakteristik sama akan dikelompokkan menjadi satu cluster.

Pada dasarnya analisis cluster menggunakan metode k-means memiliki algoritma sebagai berikut:

1. Menentukan banyanknya k cluster yang diinginkan.

2. Menentukan pusat cluster (centroid) awal secara random dari objek data sebanyak $\mathrm{k}$.

3. Menentukan jarak terdekat dari setiap objek pengamatan dengan centroid yang telah ditentukan menggunakan jarak euclidean dengan

$$
\begin{gathered}
d\left(x_{i}, x_{j}\right)=\sqrt{\sum_{l=1}^{n}\left(x_{i l}-x_{j l}\right)^{2}} \\
d\left(x_{i}, x_{j}\right)=\text { Jarak antara objek } k e \\
-i \text { dengan objek } k e \\
-j, \text { dimana } i \\
=1,2, \ldots, \mathrm{n} \text { dan } j \\
=1,2, \ldots, \mathrm{n}
\end{gathered}
$$

4. Menentukan jarak terdekat suatu objek dengan centroid.

5. Menentukan pusat cluster (centroid) baru dengan menghitung rata-rata masing-masing cluster menggunakan persamaan

$$
c_{k l}=\frac{x_{1 l}+x_{2 l}+\cdots+x_{p l}}{p}
$$

Keterangan :

$C_{k l}$ : Nilai centroid $k e-k$ pada variabel $k e-l$ $p$ :Banyaknya data 
6. Jika suatu objek tidak berpindah cluster dari jarak centroid lama dan jarak centroid baru maka ulangi langkah 3

\subsubsection{Davies-Bouldien Index}

Davies-Bouldini Index merupakan validasi cluster yang ditemukan Davidi L. Davies bersama Donaldi W. Bouldin di tahun 1979. Metode ini digunakan untuk menentukan seberapa baik clustering yang dilakukan, kohesi didefinisikan sebagai jumlah kedekatan data terhadap centroid dari cluster yang diikuti[10].

1. Sum of Square within Cluster (Sw)

$$
S w_{k}=\frac{1}{p} \sum_{l=1}^{p} d\left(x_{i l}-x_{k l}\right)=\frac{\sqrt{\sum_{l=1}^{p}\left(x_{i l}-c_{k l}\right)^{2}}}{p}
$$

2. Sum of Square between Cluster

$$
S b_{u v}=d\left(c_{u l}, c_{v l}\right)=\sqrt{\sum_{l=1}^{n}\left(c_{u l}-c_{v l}\right)^{2}}
$$

3. Rasio Cluster

$$
R_{u, v}=\frac{\left|S w_{u}-S w_{v}\right|}{S b_{u, v}}
$$

4. Menetukan rasio antar cluster maximum

$$
R_{u}=\max R_{u v}
$$

5. Davies-bouldin index

$$
D B=\frac{1}{k} \sum_{u=1}^{k} R_{u}
$$

\section{METODE PENELITIAN}

\subsection{Analisis Sistem}

Sistem yang akan dibangun pada sistem informasi geografis pengelompokan kriminalitas di Kota malang merupakan sistem untuk menginformasikan pengelompokan tingkat rawan kriminal serta menginformasikan jumlah kasus kriminal dengan menggunakan SIG pada website. Sehingga untuk dibangunnya sistem ini, dibutuhkan data-data serta informasi mengenai kasus kriminalitas di Kota Malang.

\subsection{Desain Arsitektur Sistem}

Dalam Sistem Informasi Geografis daerah rawan kriminalitas di Kota Malang, dilakukan pemetaaan daerah rawan berdasarkan Kecamatan di Kota Malang, Terlihat pada Gambar 3.1

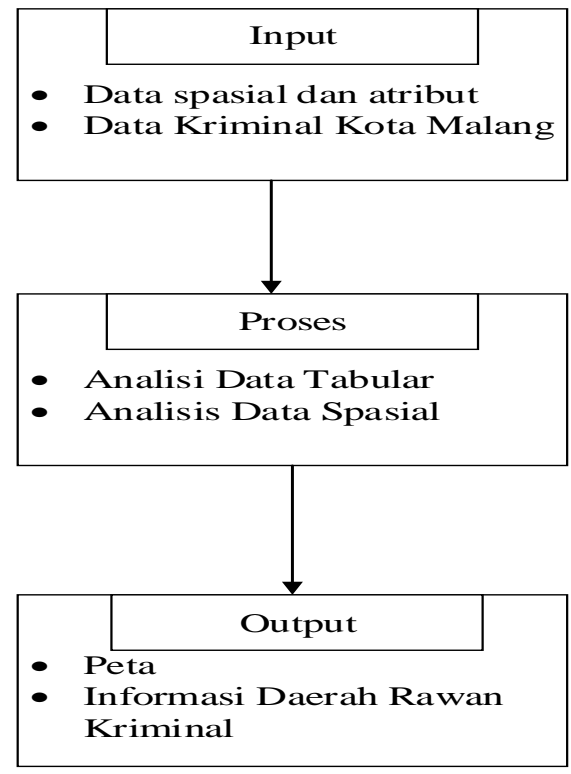

Gambar 3.1 Desain Arsitektur Sistem

Dari desain arsitektur pada gambar 3.1 diatas terdapat input, proses, dan output, berikut penjelasan mengenai desain tersebut:

1. Input

a. Data spasial dan data atribut

Data spasial adalah gambaran suatu wilayah yang terdapat di permukaan bumi. Sedangkan data atribut yaitu data berisi informasi yang dimiliki oleh obyek dalam data spasial.

b. Data Kota Malang

Data Kecamatan yang ada di dalam Kota Malang

c. Data Kriminalitas

Data dari kasus kriminalitas (Curanmor, Curas, Penganiayaan, Penadahan dan Curat).

2. Proses

a. Analisis data tabular Menganalisa data dalam bentuk tabel.

b. Analisis data spasial Menganalisis data untuk dibuat menjadi peta.

3. Output
a. Peta vektor
b. Informasi daerah rawan kriminalitas pada Kota Malang

\subsection{Flowchart SIG}

Pada bagian ini menjabarkan bagaimana alur aplikasi dari sistem informasi geografis kriminalitas Kota Malang yang telah di buat pada Gambar 3.2 


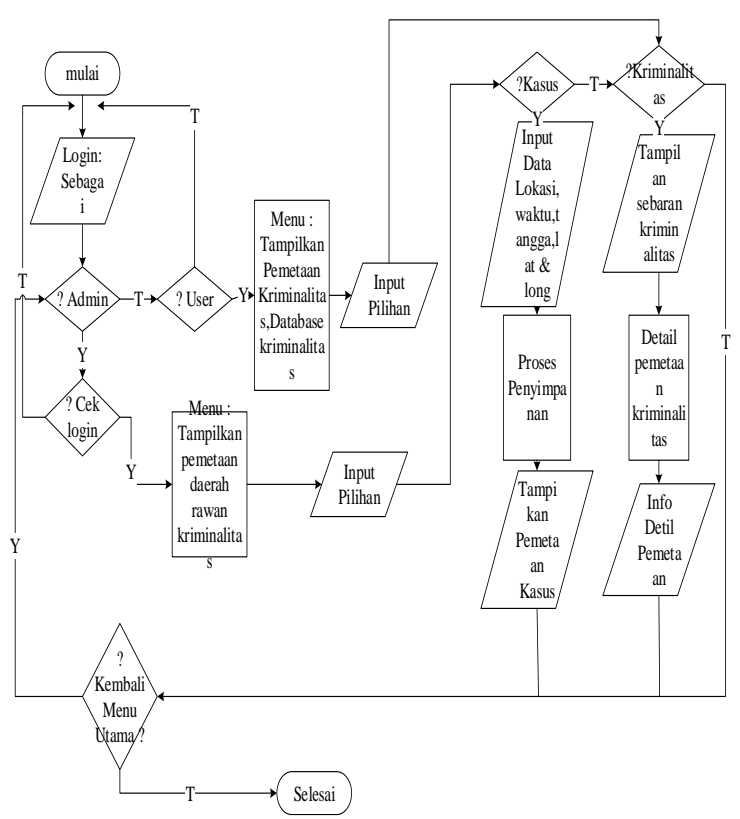

Gambar 3.2 Flowchart SIG

Pada gambar 3.2 Menjelaskan sistem dimulai dari halaman login sebagai admin dan user, ketika login dengan admin maka akan di tampilkan menu pemetaan dengan pilihan input edit pada kasus, lokasi, tanggal, waktu, latitude dan longitude. Sedangkan user biasa hanya akan di tampilkan mengenai peta persebaran kriminalitas beserta detail map yang di sajikan.

\subsection{Perancangan Database}

1. Tabel Admin

Tabel admin merupakan tabel yang digunakan untuk menyimpan data user. Tabel admin ditunjukkan pada tabel 3.1.

Tabel 3.1 Struktur Tabel Admin

\begin{tabular}{|l|l|l|}
\hline \multicolumn{1}{|c|}{ Nama Field } & \multicolumn{1}{c|}{ Jenis } & Keterangan \\
\hline id & Int & Id user \\
\hline Username & Varchar(50) & Username \\
\hline Password & Varchar(50) & Sandi \\
\hline
\end{tabular}

2. Tabel Data kriminalitas

Tabel ini berfungsi untuk menyimpan data atribut kasus kriminal dan informasi lokasi ,tanggal

\begin{tabular}{lccccc}
\hline Kecamatan & P1 & P2 & P3 & P4 & P5 \\
\hline Sukun & 32 & 12 & 9 & 5 & 4 \\
Klojen & 30 & 5 & 8 & 12 & 5 \\
Lowokwaru & 80 & 15 & 2 & 14 & 1 \\
Kedungkandang & 7 & 8 & 0 & 5 & 0 \\
Blimbing & 18 & 16 & 1 & 8 & 0 \\
\hline
\end{tabular}

\begin{tabular}{|l|c|}
\hline R12 & 5,099 \\
\hline R13 & 0 \\
\hline R14 & 0 \\
\hline R23 & $-0,101$ \\
\hline R24 & $-0,195$ \\
\hline R34 & 0 \\
\hline
\end{tabular}

dan waktu yang ada di daerah kota malang.
Deskripsi tabel dapat dilihat pada Tabel 3.2. Tabel 3.2 Struktur Data kriminalitas

\begin{tabular}{|l|l|l|}
\hline $\begin{array}{c}\text { Nama } \\
\text { Field }\end{array}$ & \multicolumn{1}{c|}{ Jenis } & \multicolumn{1}{c|}{ Keterangan } \\
\hline id & Int & Kode krimnalitas \\
\hline lokasi & Varchar(50) & Nama lokasi \\
\hline Tanggal & Date & Keterangan tanggal \\
\hline Waktu & Time & Keterangan waktu \\
\hline Lat & Int(50) & Titik koordinat (x) \\
\hline Longi & Int(50) & Titik koordinat (y) \\
\hline
\end{tabular}

3. Tabel Data Kecamatan

Tabel ini berfungsi untuk menyimpan data kecamatan. Deskripsi tabel dapat dilihat pada Tabel 3.3

Tabel 3.3 Struktur Data Kecamatan

\begin{tabular}{|l|l|l|}
\hline $\begin{array}{c}\text { Nama } \\
\text { Field }\end{array}$ & \multicolumn{1}{|c|}{ Jenis } & \multicolumn{1}{c|}{ Keterangan } \\
\hline id & Int & Kode kecamatan \\
\hline nmkec & Varchar(50) & Nama kecamatan \\
\hline
\end{tabular}

\section{Hasil Dan Pembahasan}

\subsubsection{Pengelompokan Hasil Clustering}

Berikut adalah contoh langkah perhitungan metode k-means clustering dengan data yang di peroleh dari polres Kota Malang Tahun 2019.

Tabel 4.1 Data Kasus kriminalitas

\section{Keterangan: \\ P1:Curanmor \\ P2:Penganiayaan \\ P3:Curat \\ P4:Penadahan \\ P5:Curas}

Selanjutnya Menentukan Centroid awal terlebih dahulu, penulis mengambil kasus menggunakan 4 centroid.

\begin{tabular}{|c|c|c|c|c|c|}
\hline & P1 & $\mathbf{P 2}$ & P3 & P4 & P5 \\
\hline $\mathrm{C} 1$ & 18 & 16 & 1 & 8 & 0 \\
\hline C2 & 32 & 12 & 9 & 5 & 4 \\
\hline C3 & 80 & 15 & 2 & 14 & 1 \\
\hline $\mathrm{C} 4$ & 7 & 8 & 0 & 5 & 0 \\
\hline
\end{tabular}

Tabel

Centroid Awal

Setelah nilai centroid awal sudah di tetapkan pada tabel kasus kriminal, dilanjutkan dengan menghitung jarak masing-masing data pada keempat centroid menggunakan perhitungan jarak Euclidien menggunakan persamaan (2.1)

Tabel 4.3 Jarak Euclidien dari hasil Iterasi ke-1 


\begin{tabular}{|l|l|}
\hline Sw1 & 0 \\
\hline Sw2 & 5,099 \\
\hline Sw3 & 0 \\
\hline Sw4 & 0 \\
\hline
\end{tabular}

\begin{tabular}{|l|l|}
\hline Sb12 & 17,378 \\
\hline Sb13 & 62,313 \\
\hline Sb14 & 13,964 \\
\hline Sb23 & 50,279 \\
\hline Sb24 & 26,095 \\
\hline Sb34 & 73,918 \\
\hline
\end{tabular}

\begin{tabular}{cccccc}
\hline Kecamatan & C1 & C2 & C3 & C4 & Cluster \\
\hline Sukun & 17,349 & $\mathbf{0}$ & 49,517 & 27,166 & 2 \\
Klojen & 18,841 & $\mathbf{1 0 , 1 9 8}$ & 51,536 & 26 & 2 \\
Lowokwaru & 62,313 & 49,517 & $\mathbf{0}$ & 73,918 & 3 \\
Kedungkandang & 13,964 & 27,166 & 73,918 & $\mathbf{0}$ & 4 \\
Blimbing & $\mathbf{0}$ & 17,349 & 62,313 & 13,964 & 1 \\
\hline
\end{tabular}

berikutnya menghitung jarak masing-masing data dari keempat centroid sama seperti sebelumnya. Apabila keanggotaan data ada yang berubah maka perlu di lakukan iterasi lagi sampai data setiap cluster tidak ada yang berubah.

\subsubsection{Hasil pembentukan Cluster}

1.Hasil centroid 2 cluster

\begin{tabular}{cccccc}
\multicolumn{5}{c}{ Tabel 4.4 Centroid 2 cluster } \\
\hline & P1 & P2 & P3 & P4 & P5 \\
\hline C1 & 48 & 11 & 7 & 11 & 4 \\
C2 & 13 & 12 & 1 & 7 & 0 \\
\hline
\end{tabular}

2.Hasil centroid 3 cluster

\begin{tabular}{cccccc}
\multicolumn{4}{c}{ Tabel 4.5} & Centroid 3 cluster \\
\hline & P1 & P2 & P3 & P4 & P5 \\
\hline C1 & 27 & 11 & 6 & 9 & 3 \\
C2 & 7 & 8 & 0 & 5 & 0 \\
C3 & 80 & 15 & 2 & 14 & 1 \\
\hline
\end{tabular}

3.Hasil centroid 4 cluster

\begin{tabular}{cccccc}
\multicolumn{6}{c}{ Tabel 4.6 Centroid 4 cluster } \\
\hline \multicolumn{7}{c}{ P1 } & P2 & P3 & P4 & P5 \\
\hline C1 & 18 & 16 & 1 & 8 & 0 \\
C2 & 31 & 9 & 9 & 9 & 5 \\
C3 & 80 & 15 & 2 & 14 & 1 \\
C4 & 7 & 8 & 0 & 5 & 0 \\
\hline
\end{tabular}

\subsubsection{Perbandingan keakuratan clustering}

1. Davies-Bouldin Index

Berikut tahap menghitung nilai Davies-Bouldin

Index dengan percobaan 4 cluster

a. menghitung Sum of square within cluster (Sw) menggunakan persamaan (2.3)

Tabel 4.7 hasil perhitungan $S w$

b. menghitung Sum of square between cluster (Sb) menggunakan persamaan (2.4)

Tabel 4.8 hasil perhitungan $\mathrm{Sb}$

c. Perhitungan Rasio antar cluster menggunakan persamaan (2.5)

Tabel 4.9 hasil perhit ungan Rasio

d. Menentukan rasio antar cluster maksimum menggunakan persamaan (2.6)

Tabel 4.10 rasio antar cluster

\begin{tabular}{cccccc}
\hline Rasio & $\mathbf{1}$ & $\mathbf{2}$ & $\mathbf{3}$ & $\mathbf{4}$ & $\mathbf{R}_{\max }$ \\
\hline 1 & 0 & 5,099 & 0 & 0 & 5,099 \\
2 & 5,099 & 0 & $-0,101$ & 0,195 & 4,802 \\
3 & 0 & $-0,101$ & 0 & 0 & $-0,101$ \\
4 & 0 & $-0,195$ & 0 & 0 & $-0,195$ \\
\hline
\end{tabular}

e. Menghitung nilai Davies-Bouldin Index menggunakan persamaan (2.7)

\begin{tabular}{cc}
\hline Percobaan cluster & Davies bouldin index \\
\hline 2 & 6,342 \\
3 & $-0,474$ \\
4 & 2,401 \\
\hline
\end{tabular}

Tabel 4.11 Davies Bouldin index

Dapat dilihat bahwa nilai Davies-Bouldin Index pada keseluruhan percobaan cluster memilki nilai hasil terendah pada cluster 4 yaitu sebesar 2,401. Oleh karena itu nilai yang di hasilkan adalah baik karena semakin kecil mendekati nol (tidak negatif) nilai Davies-Bouldin Index maka semakin baik keakuratan clustering.

\subsubsection{Halaman map kasus kriminalitas}

Tampilan halaman map menunjukkan informasi daerah beserta informasi persebaran kasus kriminalitas yang berada pada tiap-tiap Kecamatan di Kota Malang. Tampilan pada daerah kecamatan menunjukan nama kecamatan, sedangkan pada pada tampilan map menjelaskan mengenai lokasi, kasus, kecamatan,cluster, tanggal, waktu dan titik koordinatny. Tampilan seperti pada Gambar 4.1 


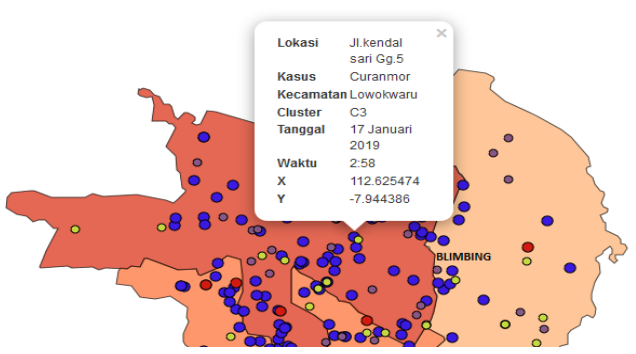

Gambar 4.1 Map Kota Malang

\subsubsection{Halaman login}

Halaman login admin ini digunakan untuk melihat semua kegiatan pengolahan data seperti menambahkan data kasus kriminalitas, melakukan edit, delete pada kasus kriminalitas, tindakan pengolahan pada data kecamatan dan data user pengguna. Pengguna harus melewati proses login terlebih dahulu seperti pada Gambar 4.2

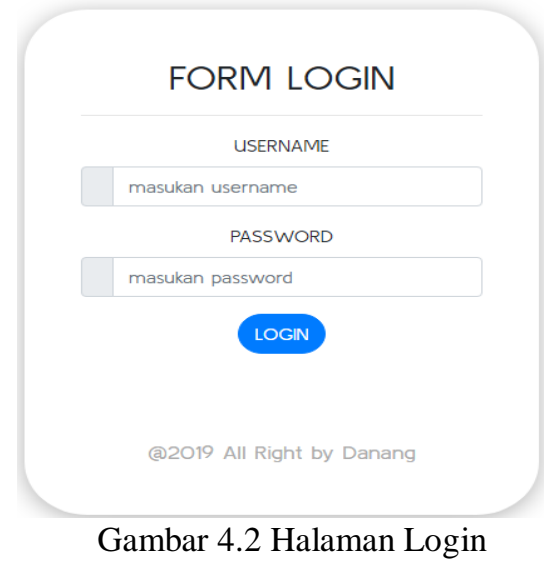

\subsubsection{Halaman Dashboard Admin}

Halaman Dashboard admin adalah halaman yang dapat di akses ketika pengguna berhasil dalam proses login , Halaman dashboard sendiri berisi mengenai pengolahan data kasus, data kecamatan dan data user

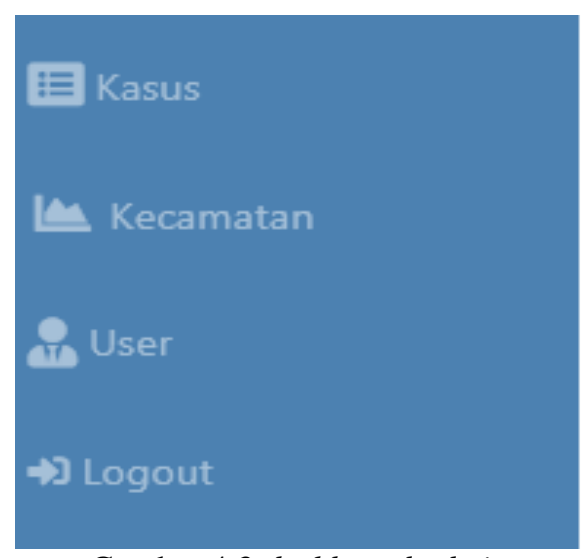

Gambar 4.3 dashboard admin

\subsubsection{Halaman list kecamatan}

Halaman ini berisi data daftar kecamatan yang telah terinputkan, Tampilan dapat dilihat seperti pada Gambar 4.4

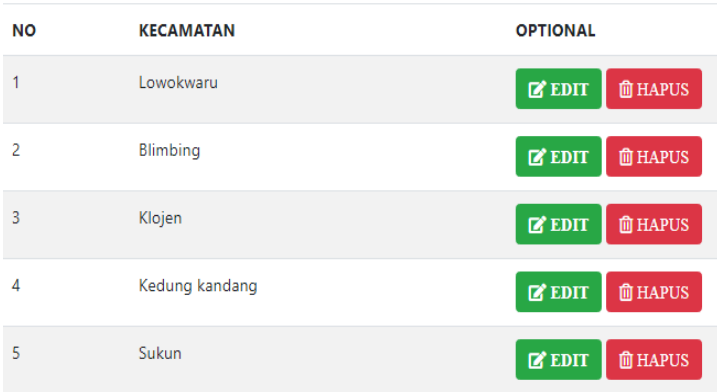

Gambar 4.4 data kecamatan

\subsubsection{Halaman Database Kasus}

Halaman ini berisi mengenai data kasus kriminalitas yang telah terjadi, Seperti pada gambar 4.5

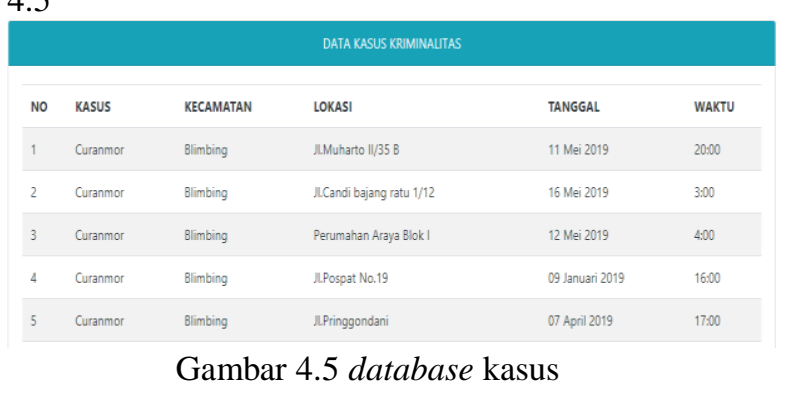

\subsubsection{Halaman Home}

Halaman ini berisi mengenai tampilan awal pada saat user menjalankan program, pada tampilan home berisi sub-menu yang ketika di akses maka akan melakukan redirect pada halaman yang dituju. Seperti pada gambar 4.6

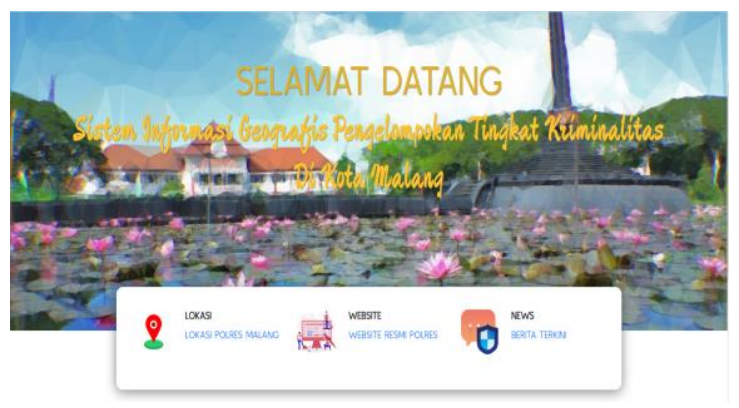

\subsubsection{Halaman Chart}

Gambar 4.6 Halaman home

Halaman ini berisi informasi chart mengenai kejadian kriminalitas tahun 2019 di Kota Malang dengan rincian kasus curanmor, curas, curat, penganiayaan dan penadahan, Seperti pada gambar 4.7

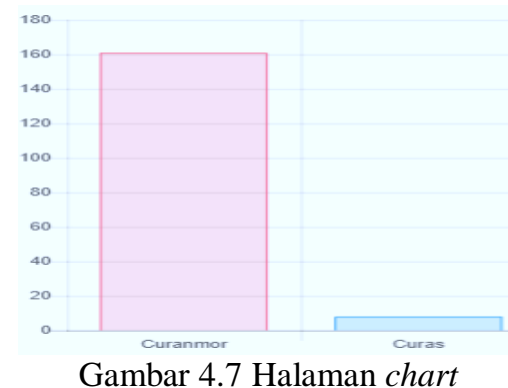

4.6 Pengujian Fungsional Sistem 
Pengujian sistem merupakan proses menampilkan sistem dengan maksud untuk menemukan adanya kesalahan atau tidak pada sistem sebelum sistem dipublikasikan untuk digunakan oleh masyarakat. Hasil pengujian sistem ditunjuakkan pada Tabel 4.12 sebagai berikut.

Tabel 4.12 Pengujian Fungsional

\begin{tabular}{|c|c|c|c|c|}
\hline \multirow[b]{2}{*}{ No } & \multirow{2}{*}{$\begin{array}{c}\text { Item Yang } \\
\text { Di Uji }\end{array}$} & \multicolumn{3}{|c|}{ Nama Browser } \\
\hline & & $\begin{array}{l}\text { Mozila } \\
\text { Firefox } \\
(\mathrm{v} .71 .0)\end{array}$ & $\begin{array}{l}\text { Google } \\
\text { Chrome } \\
(\mathrm{v} .78 .0) \\
\end{array}$ & $\begin{array}{l}\text { Microsoft } \\
\text { Edge } \\
\text { (v.44.1) } \\
\end{array}$ \\
\hline 1 & $\begin{array}{l}\text { Halaman } \\
\text { Utama } \\
\text { Website }\end{array}$ & $\checkmark$ & $\checkmark$ & $\checkmark$ \\
\hline 2 & $\begin{array}{l}\text { Halaman } \\
\text { Peta Website }\end{array}$ & $\checkmark$ & $\checkmark$ & $\checkmark$ \\
\hline 3 & $\begin{array}{l}\text { Halaman } \\
\text { Data Kasus }\end{array}$ & $\checkmark$ & $\checkmark$ & $\checkmark$ \\
\hline 5 & $\begin{array}{l}\text { Halaman } \\
\text { Tampilan } \\
\text { Chart }\end{array}$ & $\checkmark$ & $\checkmark$ & $\checkmark$ \\
\hline 6 & $\begin{array}{l}\text { Halaman } \\
\text { Utama } \\
\text { Admin }\end{array}$ & $\checkmark$ & $\checkmark$ & $\checkmark$ \\
\hline 7 & $\begin{array}{l}\text { Halaman } \\
\text { About }\end{array}$ & $\checkmark$ & $\checkmark$ & $\checkmark$ \\
\hline
\end{tabular}

Keterangan :

$\sqrt{ }=$ Berjalan

$\mathrm{x}=$ Tidak Berjalan

\section{KESIMPULAN DAN SARAN \\ 5.1 Kesimpulan}

Berdasarkan hasil dari perancangan dan implementasi dari aplikasi sistem informasi geografis pengelompokan tingkat kriminalitas di kota malang berbasis website maka dapat diambil beberapa kesimpulan yaitu:

1. Hasil clustering menggunakan K-Means menghasilkan percobaan 3 cluster yang memiliki hasil analisis keakuratan terkecil menggunakan Davies Bouldin Index yaitu sebesar 2,401 dengan pembagian daerah intensitas aman(C1) yaitu Kecamatan Kedungkandang, dalam cluster (C2) cukup rawan ada 1 Kecamatan yaitu Kecamatan Blimbing, dalam cluster (C3) rawan yaitu kecamatan Klojen dan Sukun dan dalam cluster sangat rawan (C4) yaitu kecamatan Lowokwaru.

2. SIG yang diperoleh dari hasil clustering dapat menginformasikan kepada masyarakat di Kota Malang mengenai wilayah kecamatan yang cukup aman, cukup rawan, rawan dan sangat rawan kriminalitas.

3. Berdasarkan hasil pengujian pengguna yang memilih sangat baik adalah $32 \%$, yang memilih baik $55 \%$, yang memilih cukup baik $13 \%$ dan memilih kurang baik $0 \%$.

\subsection{Saran}

Agar dalam aplikasi ini berjalan dengan baik kedepannya, maka ada beberapa hal yang perlu dilakukan yaitu sebagai berikut:

1. Pengembangan aplikasi sistem informasi geografis pengelompokan tingkat kriminalitas di Kota Malang agar dapat di tambahkan banyak atribut jenis kasus kriminal.

2. Untuk membuatkan hasil yang lebih bervariasi di perlukan metode lain untuk proses clustering seperti Fuzzy C-Means atau K-Medoid.

\section{DAFTAR PUSTAKA}

[1] BPS, 2017, Kota Malang Dalam Angka. Kota Malang : BPS

[2] Andrianto \& Jazman M. 2018.Sistem Informasi Geografis Pemetaan Titik Lokasi Daerah Rawan Kriminalitas Kota Solok. Pekanbaru : Universitas Islam Negeri Sultan Syarif Kasim Riau, 17-26

[3] Sudarsono N., Agustin Y. H., \& Pratama R., 2017 Pemetaan Daerah Rawan Kriminal Berbasis Web Di Wilayah Hukum Pengadilan Negeri Tasikmalaya. Bali : STMIK STIKOM Bali. 175-180

[4] Yuliandarmaji A., 2013. Analisis spatiotemporal kriminalitas Kota yogyakarta dengan visualisasi webgis tahun 20112012.Surakarta : Universitas Muhammadiyah Surakarta

[5] Kholil,2017.Pemanfaatan Sistem Informasi Geografis (Sig) Dalam Aplikasi Pelaporan Dan Pelacakan Kejahatan Berbasis Android.Jakarta : Politeknik Negeri Jakarta.51-58

[6] Damayanti F. N.,Piarsa I. N., \& Sukarsa I. M., 2016, Sistem Informasi Geografis Pemetaan Persebaran Kriminalitas di Kota Denpasar.Bali : Universitas Udayana. Vol 4 No.1, 22-23.

[7] Robi'in, B., 2008, Sistem Informasi Geografis Sumber Daya Alam Indonesia Berbasis Web. Yogyakarta:Jurnal Informatika, Vol 2, No. 2, Juli 2008

[8] Fujiyanti, E., \& Amalia, D. R. (2015). Pemetaan Daerah Rawan Kriminal Menggunakan Sistem Informasi Geografis Metode Clustering. Jurnal ICT STMIK IKMI Cirebon, 13-25

[9] Hawi F. N., Ramdani F., \& Rokhmawati R. I., 2018. Evaluasi Tampilan Antarmuka QGIS Dan ArcGIS Menggunakan Pendekatan UserCentered Design (UCD), Jurnal Pengembangan Teknologi informasi dan ilmu komputer, Vol.2 No.9 2850-2857

[10] Prasetyo, Eko.(2014) Mengolah Data Menjadi Informasi Menggunakan Matlab. Yogyakarta: ANDI 